\title{
固体高分子形燃料電池内の生成水の平衡電位による相状態調査 Investigation of generated water phase in PEFC based on equilibrium potential
}

\author{
○安谷屋 佳祐（九大工）水谷 千晶（九大工）前田 裕介（九大工）正 中島 裕典（九大工） \\ 正 北原 辰巳 (九大工) 正 伊藤 衡平 (九大工)
}

Keisuke Adaniya, Chiaki Mizutani, Yusuke Maeda, Hironori Nkajima,

Tatumi Kitahara, Kohei Ito

Kyushu University, 744 Motooka, Nishi-ku, Fukuoka 819-0395

\begin{abstract}
To achieve the high performance of PEFC, understanding generated water phase (liquid and gas) in it is an important issue. In this study, we try to clarify the phase through open circuit voltages (OCVs) for a cell. We experimentally investigated the OCVs under the pressure of $1 \mathrm{~atm}$ and temperature of $40{ }^{\circ} \mathrm{C}$, with changing the humidity of supplied gases and compared theoretical potentials estimated by the Nernst equation, with considering hydrogen crossover and cathode Pt oxidation. The measured OCVs decreased with increasing the relative humidity. This characteristic corresponded to the prediction by the theory. However, the quantitative agreement between them was not obtained. This considered to be caused by the dynamic change of OCVs.
\end{abstract}

Key Words: PEFC, open circuit voltage, water phase, equilibrium potential

\section{1.はじめに}

固体高分子形燃料電池（PEFC）の実用化にあたり，適正 な水管理は重要である. 高分子電解質膜 (PEM) 内のプロ トン伝導は, PEM 内の含水率に依存し, 高含水率ほど伝導 がよいため，セル内部に適度な水が必要となり，例えばガ スを加湿して供給する必要がある。一方, 過多の水を供給 すればフラッディングを引き起こしてガス輸送を妨げる.

水管理を最適化する為に, 触媒層の構成材料である白金, カーボン担持体, 電解質 (アイオノマー) の分散性, 親水・ 撥水性，および多孔性を最適化する必要がある．物質輸送 の観点から考えれば，この時，生成水の相状態が最適化手 法に影響を与える。一方で，複雑かつ微細構造を有する触 媒層において発生する生成水の相状態を直接計測する手法 はなく，触媒層の気液モデリングでは相状態を仮定した解 析が依然として進められている。

本研究では PEFC も原理的には熱力学で規定されるエネ ルギー変換器であることに着想を得，また液水生成と水蒸 気生成時ではセルの起電力に差が生じることから，本研究 ではセルの開回路電圧（OCV）を測定し，その結果と理論 起電力を比較することで, 生成水の相状態の推定すること を目指す。そこでまず OCV のガス相対湿度による変化を 計測し，同時に液水生成時と蒸気生成時の理論 OCV につ いても計算，さらにはクロスオーバーや白金酸化の影響も 考慮して両者を比較したので報告する.

\section{2、実験方法}

\subsection{OCV 測定試験}

市販の JARI 標準セル（標準 MEA）を用いて実験を行っ た. 表 1 に実験条件, 図 1 に実験装置のフロー図を示す. 各条件で測定する前に，セル内部の環境をそるえるために まず無加湿でアノードに水素，カソードに空気を各 $50 \mathrm{cc} / \mathrm{min}$ 供給し,電子負荷装置を用いてセル電圧 $0.6 \mathrm{~V}$ に調 整して， 5 分間維持した. その後, 無加湿で両極に窒素 $50 \mathrm{cc} / \mathrm{min}$ 供給し, セルの高周波抵抗（HFR）が $100 \mathrm{~m} \Omega$ 程度 になるまで乾燥させた後, 調湿したガスを供給して OCV を測定した。各相対湿度に対して 2 回 OCV を測定した。 なお，実験中セルの HFR を同時に測定することで，重要な パラメーターであるセル内部の湿度を時々刻々確認した。
Table.1 Experimental condition of OCV hold test

\begin{tabular}{|l|l|}
\hline Temperature of cell $\left({ }^{\circ} \mathrm{C}\right)$ & 40 \\
\hline Relative humidity of gases (\%) & $48,60,90$ \\
\hline Anode gas & $\mathrm{H}_{2,}, 50 \mathrm{cc} / \mathrm{min}, 1 \mathrm{~atm}$ \\
\hline Cathode gas & Air, $50 \mathrm{cc} / \mathrm{min}, 1 \mathrm{~atm}$ \\
\hline Measurement time (h) & 1 \\
\hline Active area $\left(\mathrm{cm}^{2}\right)$ & 25 \\
\hline Polymer electrolyte membrane & Nafion ${ }^{\otimes} \mathrm{NR}-212$ \\
\hline Catalyst layer & $50 \mathrm{wt} \% \mathrm{Pt} / \mathrm{C}, 0.5 \mathrm{mgPt} / \mathrm{cm} 2$ \\
\hline Gas diffusion layer & $\begin{array}{l}\text { Carbon paper, } \\
\text { thickness } 180 \mu \mathrm{m}\end{array}$ \\
\hline
\end{tabular}

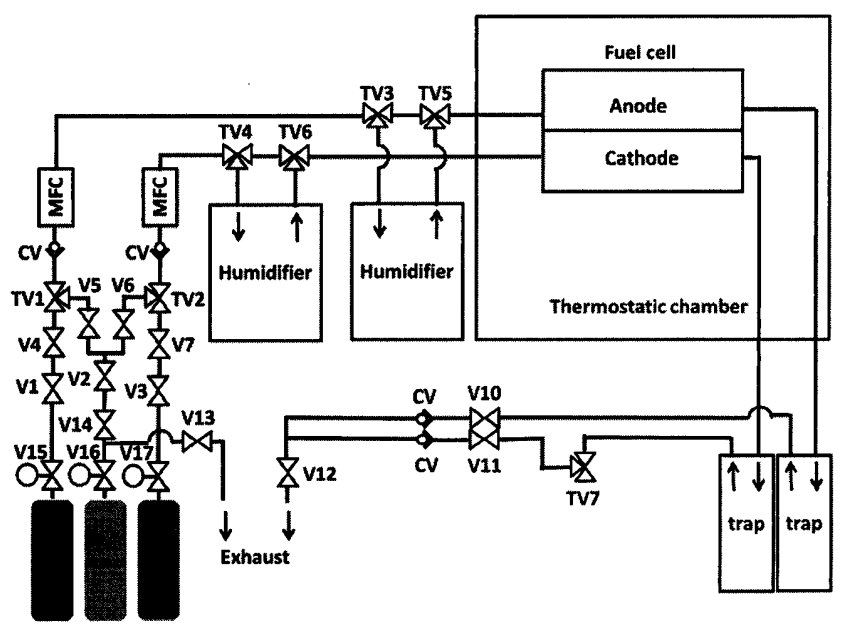

Figure.1 Experimental apparatus for OCVs measurement

\section{3. クロスオーバー等を考慮した理論起電力の導出}

PEFC の開回路時における電圧降下の主な要因は，水素 クロスオーバーとカソード白金触媒の酸化である(1). そこ で，本研究ではその 2 つ要因による電圧降下量を理論的 に見積もり，各温度，相対湿度条件下での，これら二つの 電圧降下要因を考慮した理論的 OCV を推定した。

3.1 ネルンスト式

PEFC の理論起電力は以下のネルンスト式より表される.

$$
E_{t h}=E_{c}^{0}+\frac{R T}{4 F} \ln \left[\frac{P_{O_{2}}\left(P_{\mathrm{H}_{2}}\right)^{2}}{\left(P_{\mathrm{H}_{2} \mathrm{O}}\right)^{2}}\right]
$$

$E_{c}^{0}$ はカソード標準起電力で, 以下の式で表される ${ }^{(2)}$. 


$$
E_{c}^{0}=1.229-0.000846(T-298.15)
$$
ここでTはセル温度 $(\mathrm{K}), R$ は気体定数 $\left(8.314 \mathrm{Jmol}^{-1} \mathrm{~K}^{-1}\right)$, $F$ はファラデー定数 $\left(96500 \mathrm{Cmol}^{-1}\right) . P_{\mathrm{O}_{2}}$ と $P_{\mathrm{H}_{2}}$ はそれぞれ 酸素と水素の分圧で, 調湿した空気, 水素を全圧 $1 \mathrm{~atm}$ で供 給していることから, 温度 $\mathrm{T}$ における水の飽和蒸気圧を $P_{\text {sat }, T}(\mathrm{~atm})$, 相対湿度をRH $(\%)$ とすると, $P_{O_{2}}=\left(1-P_{s a t, T} \times\right.$ $\left.\frac{R H}{100}\right) \times 0.21, P_{H_{2}}=\left(1-P_{s a t, T} \times \frac{R H}{100}\right)$ となる. また $P_{H_{2}} \mathrm{O}$ は水蒸 気分圧(あるいは水の活量) であり, 液水生成時は $P_{H_{2} O}=1$,

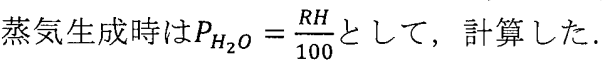

3.2 クロスオーバーの影響

水素ガスのクロスオーバーによる電圧降下は以下のバト ラー・ボルマーの式により表される.

$$
i=i_{O_{2}}^{0}\left[\exp \left(\frac{\alpha n F \eta}{R T}\right)-\exp \left(-(1-\alpha) \frac{n F \eta}{R T}\right)\right]
$$

ここで $i$ はクロスオーバー電流密度 $\left(\mathrm{A} / \mathrm{cm}^{2}\right), i_{O_{2}}^{0}$ はカソー ド交換電流密度, $\alpha$ は電荷移動係数 $(=0.5)$ で, $n$ は反応電 子数（=2）である. 式[3]よりクロスオーバーによる電圧 降下 $\triangle E_{H_{2}-\text { xover }}^{O C V}$ 次のようになる.

$$
\eta=\frac{R T}{\alpha n F} \sinh ^{-1} \frac{i}{2 i_{O_{2}}^{0}}\left(=\Delta E_{H_{2}-x o v e r}^{O C V}\right)
$$

文献より引用した交換電流密度 $i_{O_{2}}^{0}=2.43 \times 10^{-4} \mathrm{Acm}^{-2(1)}$ 用いた. クロスオーバー電流㣿以の式[5]で求めた ${ }^{(3)}$.

$$
\begin{aligned}
i=n F \times\{-2.6492 & +0.0180(T-273.15) \\
& +0.0036 R H+0.5992 P_{H_{2}} \\
& \left.+10.840(\ln t)^{-1}\right\} \times 10^{-9}
\end{aligned}
$$

$t$ は電解質膜の厚さで $t=51 \mu m$ である.

\section{3 白金酸化の影響}

カソード白金触媒の酸化による電圧降下は，高電位（低 流密度）域において, 白金表面が酸化し, 交換電流密度が 小さくなることに起因する，その影響を考慮した交換電流 密度 $i_{O_{2}(\mathrm{Pt} / \mathrm{PtO})}^{0}$ は以下の式[6]で表される ${ }^{(4)}$.

$$
i_{O_{2}}^{0}=(\mathrm{EPSA})_{c} i_{O_{2}(\mathrm{Pt} / \mathrm{PtO})}^{0}\left(\frac{P_{O_{2}}}{P_{O_{2}}^{0}}\right)^{0.001678 T}
$$

式[6]において, (EPSA) $)_{c}$ は白金の電気化学的有効表面積で, $(\mathrm{EPSA})_{c}=168 \mathrm{~cm}^{2} / \mathrm{cm}^{2(4)}$ とした. また, $P_{O_{2}}^{0}$ は酸素の標準圧 力で $P_{O_{2}}^{0}=1 \mathrm{~atm}$ とた.式[6]で得られた, $i_{O_{2}(\mathrm{Pt} / \mathrm{PtO})}^{0}=1.57 \times$ $10^{-6} \mathrm{Acm}^{-2}$ を式[4]の $i_{O_{2}}^{0}$ に代入することで, クロスオーバー, カソード白金の酸化の 2 つの要因を考慮した電圧降下 $\Delta E_{H_{2}-\operatorname{OCV} \operatorname{OV}(\mathrm{Pt} / \mathrm{PtO})}$ が以下の式[7]のように表すことができる. また，補正した OCV ( $E_{\text {Corrected }}^{\text {OCV }}$ ) は式[8]で表される.

$$
\begin{aligned}
& \Delta E_{H_{2}-\text { xover }(\mathrm{Pt} / \mathrm{PtO})}^{O C V}=\frac{R T}{\alpha n F} \sinh ^{-1} \frac{i}{2 i_{O_{2}(\mathrm{Pt} / \mathrm{PtO})}^{0}} \\
& E_{\text {Corrected }}^{O C V}=E_{\text {Measured }}^{O C V}+\Delta E_{H_{2}-\text { xover }(\mathrm{Pt} / \mathrm{PtO})}^{O C V}
\end{aligned}
$$

4 結果と考察

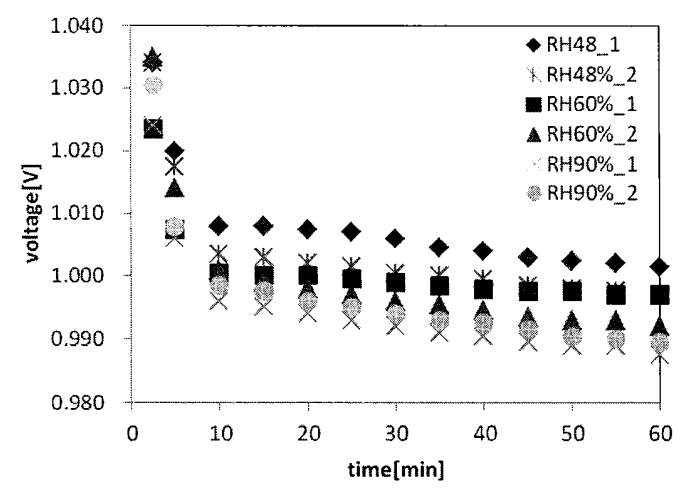

Figure. 2 OCVs under the cell temperature of $40^{\circ} \mathrm{C}$ with different relative humidity. Each number in graph legends corresponds to the order of experiment. OCVs in any case decreased with time elapsed.

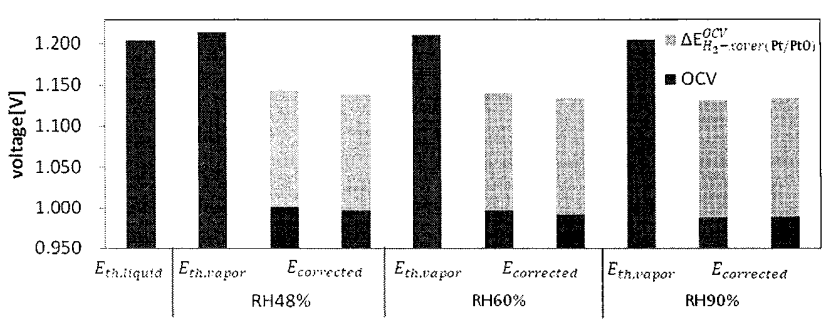

Figure.3 Corrected OCVs and theoretical potential at $40^{\circ} \mathrm{C}$ with different humidity.

図 2 は各相対湿度のガスを流し始めた後の OCV の変化 である。どの相対湿度においても, 一度山なりに上昇し, 降下する. 降下速度は 7 分後程度までは急で, その後緩や かとなる．急な降下は物質輸送の緩和で，その後緩やかな 降下は白金の酸化と考えられる。本研究では，物質輸送が 十分に緩和したと考えられる 60 分を各相対湿度に対する OCV と定義し，以下，理論值との比較対象とした.

図 3 は各相対湿度に対する実験で求めた 60 分後の OCV と, 理論值の比較である. 実験でもとめた OCVには 3 章

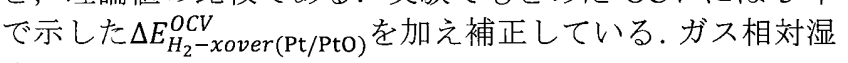
度が上昇すると実測した OCV は低くなった。この傾向は 理論值と一致した。相対湿度が高くなると, 式[1]における $P_{\mathrm{H}_{2} \mathrm{O}}$ が相対的に大きくなり， $P_{\mathrm{O}_{2}}, P_{\mathrm{H}_{2}}$ がともに小さくなる ためである。

このように定性的には実測值と理論值で一致がみられた が，補正してもなお OCV は理論值よりも約 $70 \mathrm{mV}$ 低い值 となった. 本研究における OCV の実験值は, 水蒸気の物 質輸送が十分に落ち着く60 分後の值と定義した. この 60 分を指示する強い理由はなく, 例えば 10 分後などとすると 補正した実測值と理論值はより一致する。しかしながら 10 分などと短時閒であれば，白金酸化の平衡には達していな いとも考えられる. 今後は実測時に現れる OCV の時間変 化を考慮した害測值の補正など, より詳細に OCV を捕ら える予定である。

このように定量的な一值は見られなかったが，図 2 から $\mathrm{RH}=100 \%$ と $\mathrm{RH}=40 \%$ OCV の理論值の差異は, 実測のそ れと概ね合致 (約 $10 \mathrm{mV}$ ) する。このことから, 本研究で 最初に提案した OCV から相状態を特定できる可能性が示 唆される.

\section{まとめ}

PEFC の OCV を $40^{\circ} \mathrm{C}, \mathrm{RH} 48,60,90 \%$ で測定し, 相対 湿度による変化の傾向を測定し, その結果と理論值を比較 して, 生成水の相状態の推定を試みた。結果より, 相対湿 度が高くなる程, OCV は低くなる．つまり，より生成水の 液水の割合が高くなることがわかった。 しかし, 定量的に は, 補正してもなお理論值よりも低い值となった。今後は, 時間変化を考慮にいれた実測值の補正など、より詳細に実 測値と理論值を比較し、OCV から水の相状態を特定する。

\section{参考文献}

(1)Jianlu Zhang, Yanghua Tang, Chaojie Song, Jiujun Zhang, Haijang Wang, J. Power Sources 163 (2006) 532-537.

(2)J.C. Amphett, R.M. Baumert, R.F. Peppley, P.R. Roberge, T.J. Harris, J. Electrochem. Soc. 142 (1995) 9.

(3)Kyung Don Baik, Bo Ki Hong, Min Soo Kim, Renewable Energy 57 (2013) 234-239

(4)Chaojie Song, Yanghua Tang, Jian Lu Zhang, Jiujun Zhang, Haijiang Wang, Jun Shen, Scott McDermid, Jing Li, Paul Kozak, Electrochimica Acta 52 (2007) 2552-2561. 